\title{
Paradigmas do estudo da religião: as contribuições de Jean Greisch
}

Paradigms of the study of religion: the contributions of Jean Greisch

Geraldo Luiz De Mori*

\begin{abstract}
Resumo
São muitas as abordagens do fenômeno religioso surgidas nos últimos dois séculos. Algumas recorrem aos métodos elaborados pelas ciências humanas, sobretudo a historiografia, a sociologia, a etnologia/antropologia, a psicologia e a fenomenologia. Outras tratam a religião numa perspectiva filosófica, como se pode ver nos grandes autores que, sobretudo a partir do século XIX, se consagraram à elaboração de uma filosofia da religião. Nas últimas décadas, com a renovação da filosofia hermenêutica, novas leituras da religião têm surgido, renovando profundamente esse campo do saber. O texto aqui proposto apresenta alguns elementos da grande síntese do filósofo luxemburguês Jean Greisch, pouco conhecido no Brasil, mas cuja contribuição ao estudo da religião é original, privilegiando uma hermenêutica da passagem. Após uma breve apresentação de sua obra consagrada à filosofia da religião, serão apresentados os cinco "paradigmas" dos estudos da religião segundo ele: o especulativo, o crítico, o fenomenológico, o analítico e o hermenêutico, o último seguido pelo próprio autor.
\end{abstract}

Palavras-chave: Jean Greisch; hermenêutica; religião; paradigmas; passagem.

\begin{abstract}
There are many approaches on the religious phenomenon that emerged in the last two centuries. Some resort to methods devised by the humanities, especially historiography, sociology, ethnology/anthropology, psychology, and phenomenology. Others treat religion in a philosophical perspective, as can be seen in the great authors who, especially from the nineteenth century, devoted themselves to the elaboration of a philosophy of religion. In recent decades, with the renewal of hermeneutic philosophy, new readings of religion have emerged, profoundly renewing this field of knowledge. The text proposed here presents some elements of the Luxembourg philosopher Jean Greisch's great synthesis, little known in Brazil, but whose contribution to the study of religion is original, favoring a hermeneutics of the passage. After a brief presentation of his work devoted to the philosophy of religion, the five "paradigms" of religious studies, according to him, will be presented: the speculative, the critical, the phenomenological, the analytical and the hermeneutic, the last followed by the author himself.
\end{abstract}

Keywords: Jean Greisch; hermeneutics; religion; paradigms; passage.

\footnotetext{
Artigo submetido em 14 de junho de 2019 e aprovado em 29 de agosto de 2019.

* Doutor em Teologia pelo Centre Sèvres - Facultés Jésuites de Paris. Professor da FAJE. País de origem: Brasil. E-mail: geraldodemori@faculdadejesuita.edu.br
} 


\section{Introdução}

São muitas as abordagens do fenômeno religioso nos últimos dois séculos. Na análise panorâmica que Paulo Antônio Couto Faria fez em sua tese doutoral, ele elenca os seguintes campos do saber que se interessam por esse fenômeno: História da religião (e suas variantes História comparada das religiões, História das religiões); Fenomenologia da religião (e as perspectivas de Gerardus Van der Leeuw, Rudolf Otto, Mircea Eliade); Ciências sociais da religião (e os enfoques de Émile Dürkhein, Max Weber, Karl Marx, Pierre Bourdieu, Georg Simmel, Gabriel Le Bras); Psicologia da religião (e as leituras de Freud e Jung); Filosofia da Religião, pouco aprofundada pelo autor, mas que contou com os aportes, entre outros, de Hegel, Schleiermacher, Kierkegaard, Ricoeur (FARIA, 2016, p. 17-99). Manuel Marzal, em sua obra sobre a antropologia religiosa latino-americana, observa que a religião tem sido objeto de enfoques de tipo evolucionista, estruturalfuncionalista e simbólico (MARZAL, 2002, p. 65-94). Não é interesse deste estudo revisitar essas abordagens e esses enfoques, mas trazer para o público brasileiro as contribuições de Jean Greisch, filósofo luxemburguês, ao estudo das correntes hermenêuticas no estudo da religião. Após uma breve apresentação do autor e da estrutura de sua principal obra sobre a filosofia da religião ${ }^{1}$, serão retomados alguns dos elementos do "paradigma hermenêutico", proposto por ele para interpretar o fenômeno religioso.

\section{Jean Greisch: uma hermenêutica da "passagem"}

Jean Greisch nasceu em 1942, em Koerich (Luxemburgo). Realizou seus estudos em filosofia e teologia no próprio país, completando-os em Innsbruck (Áustria) e Paris. Foi docente na Faculdade de Filosofia do Institut Catholique de Paris, da qual foi decano entre 1985-1994, diretor do ciclo do doutorado e do laboratório de filosofia hermenêutica e fenomenologia. Suas principais pesquisas estão relacionadas com o problema contemporâneo da ontologia, entrecruzado às questões da tradição hermenêutica, em seus antecedentes teológicos, mas,

\footnotetext{
${ }^{1}$ Esta obra foi publicada em três volumes, dois em 2002 e um em 2004.
} 
sobretudo, em suas releituras filosóficas no pensamento contemporâneo. Já em sua primeira obra importante, Herméneutique et grammatologie, ele buscou realizar um primeiro confronto sistemático entre a hermenêutica de Gadamer, com seus antecedentes em Dilthey e Heidegger, e o pensamento da "différance”, tal qual foi abordado por Derrida. Por detrás da oposição entre "Palavra" e "Escritura", se desenha, segundo ele, uma oposição mais fundamental, como a do "compreender" e "interpretar", que, por sua vez, remete às problemáticas da "essência" e da diferença ontológica, ambas herdadas de Heidegger. De fato, várias de suas obras tratam temas heideggerianos, como Herméneutique et grammatologie (Paris, 1977); L’Âge herméneutique de la raison (Paris, 1985); La Parole heureuse. Martin Heidegger entre les choses et les mots (Paris, 1987); Hermeneutik und Metaphysik (München, 1993); Ontologie et temporalité. Esquisse d'une interprétation intégrale de Sein und Zeit (Paris, 1994); L'Arbre de vie et l'arbre du savoir. Les racines phénoménologiques de l'herméneutique heideggérienne (Paris, 2000). Greisch é também um grande intérprete da hermenêutica de Paul Ricoeur, como atesta sua obra: Paul Ricour: l'itinérance du sens (Grenoble, 2001), embora tenha uma perspectiva própria, como se pode ver em suas obras: Entendre d'une autre oreille: les enjeux philosophiques de l'herméneutique biblique (Paris, 2006); L'Herméneutique comme sagesse de l’incertitude (Paris, 2016). Ele se destacou ainda por sua pesquisa em filosofia da religião: Le Buisson ardent et les Lumières de la Raison. L’invention de la philosophie de la religion. Tome I: Héritiers et Héritages du XIX ${ }^{\mathrm{e}}$ siècle (Paris, 2002); Tome II: Les approches phénoménologiques et analytiques (Paris, 2002); Tome III: Vers un paradigme herméneutique (Paris, 2004). É, sobretudo, ao último tomo desta obra que é consagrado este estudo, pois nele o autor articula sua reflexão hermenêutica, em diálogo com seus predecessores, e sua reflexão sobre a religião.

$\mathrm{Na}$ introdução à obra em homenagem a Greisch, que, em 2004, lhe dedicaram seus colegas e amigos, os organizadores explicam, na apresentação, o motivo da escolha da temática geral: a preocupação pela “passagem”. Segundo eles, ao comentar e traduzir Heidegger e Dilthey, Gadamer, Jonas e Ricoeur, discutindo suas teses, confrontando seus conceitos, aproximando seus caminhos, Greisch 
manifestou uma preocupação pela passagem: entre o francês e o alemão, as duas línguas de seu país, entre a fenomenologia e a filosofia da religião, entre a metafísica e a teologia, entre as ciências humanas e a hermenêutica, entre a poesia e a ética (CAPELlE, P.; HÉBERT, G.; POPELARD, M.-D., 2004, p. 7). Por seu ensino, sua atividade de tradutor, conferencista e autor, ele realiza vários tipos de passagem e lança pontes, abrindo brechas, ajeitando transições, inventando traçados. No texto que escreveu na mesma obra, Stanislas Breton analisa o termo passagem e quem exerce esse ofício. Citando Eckhart, para o qual "de Deus, sob o nome de ser, e sob qualquer outro nome, é preciso que a alma só faça um lugar de passagem, ele diz que não só de Deus, mas também das obras filosóficas se pode dizer isso, que elas nada mais são do que uma forma de passagem. É preciso passar por elas, reter o que deram, mas não esquecer que são e devem permanecer um lugar de passagem. Sua mediação não pode se tornar ídolo, seja no âmbito da filosofia seja no da espiritualidade. Quem passa alguém para a outra margem, deve assegurar aos passantes uma autêntica travessia (BRETON, 2004, p. 14). A função do mediador, muito explorada na filosofia, e também na teologia cristã, que une na mesma pessoa as duas naturezas extremas a serem reconciliadas: Deus e o ser humano. Todo mediador tem a função de fazer passar de uma margem à outra os extremos que habitam sua pessoa. Sem sombra de dúvida, Greisch é um desses mediadores que ajudam a fazer a passagem, conduzindo seus leitores de uma margem à outra, ajudando-os a conhecerem o caminho que atravessam, mas abrindo-os também a novas descobertas, que lhe vão sendo dadas no próprio percurso da travessia e pelo modo como foi conduzido a realizá-lo.

\section{A sarça ardente e as luzes da razão}

Os três volumes da obra de Greisch sobre a filosofia da religião são, conforme o autor diz na introdução, o resultado de sua pesquisa e ensino para estudantes de mestrado em filosofia e teologia no Institut Catholique de Paris. O autor pretende, nesta obra, oferecer uma “iniciação histórica à filosofia da religião" (GREISCH, 2002, p. 7). Para ele, a principal dificuldade da ideia de filosofia da religião é a tensão constitutiva entre "a sarça ardente", como modo de aparecer 
específico e irredutível da verdade religiosa", e as "luzes da razão", em sua tarefa crítica de construção da verdade filosófica. Para não permanecer num impasse, esta tensão fixa as tarefas da filosofia da religião, que Greisch articula ao redor dos seguintes temas: a essência da religião, o sentido da pluralidade e da sucessão histórica das religiões positivas, a pretensão à verdade das distintas religiões, a busca hipotética de uma religião absoluta (GREISCH, 2002, p. 33). Esses temas são dinâmicos e sua articulação é tributária da própria história da filosofia da religião, que os organiza em diálogo com a teologia e as ciências da religião² ${ }^{2}$ O filósofo da religião se interessa ainda pelo futuro da religião, sobretudo nas sociedades secularizadas, não se esquecendo tampouco de se interrogar pelo presente e pela natureza de seu objeto, a religião.

Fixadas essas premissas, pode-se dizer que a obra de Greisch apresenta um panorama da história da filosofia da religião em seu desenvolvimento cronológico. O autor não se contenta, porém, em apresentar os diferentes autores e épocas, mas escolhe os que, direta ou indiretamente, continuam influenciando os debates filosóficos e teológicos contemporâneos (GREISCH, 2002, p. 60). Apesar de privilegiar autores que se relacionam com o cristianismo, ele se volta igualmente para autores judeus. Sua pesquisa é restrita à área cultural germânica, francófona e anglo-saxônica. Como opção metodológica, ele segue a perspectiva weberiana dos modelos ideal-típicos, que privilegiam a abordagem por paradigma, cada um pressupondo um conceito específico da própria razão (GREISCH, 2002, p. 61). Greisch propõe cinco paradigmas: especulativo e crítico (Tomo 1), fenomenológico e analítico (Tomo 2), hermenêutico (Tomo 3). A vantagem desse método é que ele permite romper a tentação de uma história especulativa da filosofia da religião, já que esses paradigmas podem coexistir na modernidade recente, e podem se articular para além do próprio século que os viram emergir.

\footnotetext{
${ }^{2}$ Em geral Greisch não utiliza a expressão "ciências da religião", mas "ciências religiosas" ou "estudos da religião".
} 


\subsection{Os paradigmas especulativo e crítico do estudo da religião}

Os paradigmas especulativo e crítico são estudados no primeiro tomo da obra de Greisch, que ele divide em duas grandes partes. A primeira, dedicada ao paradigma especulativo, começa com a explicação do termo especulativo. Segundo Greisch, esse termo tem origem no latim “specula”, e designa, por um lado, o promontório a partir do qual se contempla do alto uma paisagem, significando, em filosofia, as pretensões e aspirações filosóficas que visam a uma explicação englobante do real, à luz do absoluto. Por outro lado, "speculum" remete também a espelho, no qual se reflete tudo o que é. Na filosofia, a metáfora lembra, em primeiro lugar, os graus de contemplação, a especulação ocupando um estádio inferior em relação à visão. Num segundo sentido, "speculum" lembra a distinção aristotélica entre ciências teoréticas (especulativas) e ciências práticas. Em Kant, a distinção se estabelece entre "entendimento" (Verstand) e "razão especulativa" (Vernunft), o primeiro indicando o poder de julgar, implicado em todo processo cognitivo dirigido pela experiência, e a segunda remetendo à faculdade de produzir ideias transcendentais: mundo, alma, Deus (GREISCH, 2002, p. 62). O filósofo de Königsberg é crítico do uso especulativo da razão, que pretendia conhecer a coisa em si, conhecimento reservado, segundo ele, ao intelecto divino. Ele lhe reserva, porém, o papel de regulador da razão. Sua recepção pelos principais representantes do idealismo alemão (Fichte, Schelling e Hegel) representa o apogeu do paradigma especulativo. Nesse paradigma, Greisch inclui F. D. E. Schleiermacher, G. W. F. Hegel, F. W. J. Schelling, F. Rosenzweig, K. Rahner.

Numa época extremamente crítica da religião, Schleiermacher acredita que só se pode entendê-la desde dentro, a partir dela mesma. Por isso, a própria religião deve definir o terreno sobre o qual ela se situa, que é irredutível ao da moral e da metafísica. Ela é o brotar do mais íntimo da alma e constitui sua província autônoma (GREISCH, 2002, p. 82). Articulando intuição e sentimento, o autor define a religião como sentido e gosto do Infinito, que leva o fiel a se sentir absolutamente dependente. Para ele, Deus é dado originalmente ao fiel no 
sentimento. Logo, a religião é o sentimento de dependência absoluta (GREISCH, 2002, p. 88).

Para Hegel, ao sair do iluminismo, a religião se tornou um "iluminismo insatisfeito", que é uma consciência frustrada, habitada por uma sede de absoluto insatisfeita racionalmente. A tentação então era se refugiar no sentimentalismo pietista e no fervor religioso, incapazes de ouvir a "música do conceito" (GREISCH, 2002, p. 125). Como reação, a ortodoxia teológica havia psicologizado, moralizado e humanizado seus conteúdos. Para se reencontrar o autêntico saber de Deus, era preciso reabilitar sua dignidade teórica. A filosofia da religião é a explicitação especulativa da ideia do cristianismo e se articula num esquema que tem como ponto de partida o conceito geral de religião, passa à religião determinada e culmina na religião absoluta, voltada ao movimento do conceito. O absoluto é "a região que soluciona os enigmas do mundo, as contradições do pensamento e as dores do sentimento" (GREISCH, 2002, p. 132).

Schelling quer pensar o Absoluto em sua realidade viva. Para isso, ele propõe uma filosofia da história cuja trama é fornecida pelo próprio Absoluto, que se diz numa filosofia da mitologia e numa filosofia da revelação. O conjunto da história, segundo ele, é uma revelação contínua do Absoluto, que se desvela progressivamente e nunca é totalmente completa (GREISCH, 2002, p. 182). A ação divina na história é o verdadeiro objeto da filosofia. As representações mitológicas, segundo Schelling, devem ser tidas como a verdade plena e inteira, ou seja, como doutrina sobre os deuses (GREISCH, 2002, p. 188). Quanto ao objeto da revelação, mais que uma doutrina, diz o filósofo alemão, trata-se de um fato ou de uma série de fatos cuja fonte é o próprio Absoluto. Tudo o que ela sabe dizer da revelação, a filosofia da revelação só poderá dizê-lo após o fato ter efetivamente acontecido (GREISCH, 2002, p. 196).

Na obra de Rosenzweig, o tema da revelação joga um papel central, significando orientação e a ambição de fundar a ideia de razão no conceito de revelação (GREISCH, 2002, p. 210). Para isso, ele traduz sua intuição num sistema 
de relações lógicas, cujo ponto de partida é a mística negativa. Deus, o ser humano e o mundo, captados inicialmente pela razão sob o signo da separação, são, em seguida, pensados sob o signo da relação. Esta relação não tem nada de formal, pois se trata do encontro do ser humano com Deus, consigo mesmo, com o outro e com o mundo. O evento deste encontro é a revelação. O próprio Deus se dissimula quando se quer compreendê-lo. O ser humano e seu eu se fecham, e o mundo se torna enigma. Deus, ser humano e mundo só se abrem em suas relações na criação, na revelação e na redenção.

Para Rahner, o conhecimento do Deus da metafísica se confunde com as trevas da ignorância humana sobre o ser divino. Este conhecimento "tenebroso" só se torna "luminoso" sob o efeito de uma livre auto comunicação de Deus. O ser humano, segundo ele, torna-se o destinatário da Palavra de Deus da qual ele não sabe nada antes que ela lhe seja dirigida (GREISCH, 2002, p. 278). A teologia, mais que refletir sobre o conjunto dos dados dogmáticos, deve se perguntar pela livre revelação de Deus que escolhe falar à humanidade. Para isso, ela deve saber se o ser humano é apto a se tornar o destinatário de uma possível Palavra de Deus. Para Rahner, se a historicidade é constitutiva do ser humano, então ele é desde sempre aberto a uma possível revelação de um Deus livre e desconhecido no seio da história. Esta abertura à revelação só é possível porque o ser humano é capaz de ouvi-la e a ela obedecer livremente.

Na segunda parte de sua obra, dedicada ao paradigma crítico, Greisch também apresenta os significados do criticismo. Num primeiro sentido, o termo se refere a Kant e à história de sua recepção. O questionamento crítico é de tipo transcendental, ou seja, ele diz respeito à efetividade e às condições de possibilidade de todo saber. Trata-se de entender os interesses da razão que se articulam ao redor das questões: que posso conhecer? Que devo fazer? Que me é permitido esperar? O que é o ser humano? A terceira questão é o fio condutor da interrogação de Kant sobre a Religião no interior dos limites da simples razão (1793). Esse texto fundador, observa Greisch, mostrou, desde o final do século XIX, a via às numerosas filosofias da religião que emanam do neokantismo, como a de 
H. Cohen, E. Troeltsch, P. Tillich, H. Duméry. Um segundo sentido de crítico é o dos autores que reduziram a transcendência religiosa a mero sentido antropológico, desembocando no ateísmo, como L. Feuerbach, F. Nietzsche, E. Bloch.

Segundo Greisch, Kant propõe um novo paradigma para pensar Deus, no qual a teologia moral substitui a cosmo-teologia e a teologia especulativa (metafísica). Como a moral tem sua fonte na liberdade, Deus não é mais pensado em termos de ser supremo, mas de liberdade (GREISCH, 2002, p. 311). O filósofo de Königsberg realiza primeiro, na Crítica da razão pura, um trabalho de desconstrução, com a crítica radical das pretensões cognitivas em matéria de conhecimento de Deus, a começar pelas provas de sua existência. Na Crítica da razão prática, ele mostra que a fonte da moral é a própria moral e introduz os postulados da razão prática (alma, liberdade e Deus), necessários para a noção de soberano bem. Na Religião nos limites da simples razão, ele propõe pensar Deus como o ideal transcendental e guardião da unidade e da totalidade do saber. O enigma do mal moral é para ele a chave de leitura da filosofia da religião.

Hermann Cohen se interroga sobre a acolhida da religião no sistema filosófico do saber. Para ele, o saber repousa sobre a consciência, refletida na lógica ou na ciência (diante da natureza), na ética (frente à vontade) e na estética (face ao sentimento). A psicologia filosófica assegura o vínculo sistemático entre esses campos do saber. A religião não possui um campo próprio nesse sistema, embora se relacione com todos. De fato, ao colocar a questão de Deus, ela deve pensar a questão lógica da unicidade divina (GREISCH, 2002, 356). Ao contribuir na construção do "eu ético", a partir da confissão singular do pecado, ela se torna a guardiã da singularidade dos indivíduos. Ao suscitar afetos específicos, como a compaixão e a misericórdia, que são irredutíveis aos sentimentos estéticos, ela suscita a ideia religiosa de Deus, a espera da salvação e da libertação, que têm na oração sua linguagem elementar. A psicologia, que é responsável pela unidade da consciência, completa a articulação, através da ideia da correlação, que oferece uma visão articulada da unidade da consciência cultural da humanidade. 
Para Troeltsch, mais que desenvolver o conceito de Deus é necessário estudar as religiões históricas, concretas e vivas. Em diálogo com a sociologia da religião de Max Weber e a psicologia da religião de William James, ele propõe os três tipos de relação com a religião: o de igreja, o de seita e o de mística. Crítico da transformação das faculdades de teologia em faculdades de ciências religiosas, ele pensa que a questão da normatividade da religião não pode ser eludida, embora seja necessário rever a noção de religião absoluta, que é baseada na ideia de que há uma única essência da religião, cuja mediação é a história e a manifestação definitiva o cristianismo (GREISCH, 2002, p. 393). A tarefa da filosofia da religião é determinar a essência da religião, manifesta através dos registros da psicologia, da teoria do conhecimento, da filosofia da história e da teologia filosófica. É de Troeltsch o conceito de "a priori religioso".

Paul Tillich é, segundo Greisch, mais sensível às urgências do momento e isso o leva a reabilitar a noção de kairós, consciente de que a consciência da história tem suas raízes nas profundezas do Incondicionado (GREISCH, 2002, p. 416). Influenciado pela teologia dialética de Barth, ele se pergunta, porém, se a noção de crise do teólogo suíço é suficiente para se pensar a história. Esta noção, diz ele, deve desembocar numa nova criação, pondo em relação religião e cultura. Nas sociedades, a religião não é uma função espiritual entre outras, mas a experiência do elemento do Incondicionado no interior de todas as outras funções. O estudo teórico da religião repousa, segundo ele, nas categorias do mito e da revelação, polaridade que atravessa a história religiosa da humanidade. Na esfera ético-prática, ele busca estabelecer a reconciliação teonômica entre o culto, que é sustentado pela presença gratuita do Incondicionado, e o ethos.

Henry Duméry sustenta que a fé não é apenas apelo emotivo, elã do coração. A história, diz ele, só conhece religiões positivas. Sem celebração cultual, sem fé comum, a religiosidade é possível, mas é vaga, flutuante, ineficaz. É pelo rito, pelo mito e pela representação que o ser humano reza, invoca, adora (GREISCH, 2002, p. 444). O estudo crítico da religião deve, porém, rejeitar as três formas de engano do imediatismo puro: o subjetivismo, que reduz a religião a um estado de alma, a 
um afeto bruto; a palavra kerigmática, que faz da religião um puro acontecimento; o positivismo histórico, que busca atingir o sentido verdadeiro da religião recorrendo aos fatos brutos, históricos ou sociológicos, abstraindo do sentido dos testemunhos.

Feuerbach é o primeiro autor estudado por Greisch a pensar a crítica à luz da redução da teologia à antropologia. Inicialmente seduzido pelo charme de um “Deus metamorfoseado em conceito", ele passou sua vida buscando se libertar deste mundo encantado do panteísmo hegeliano (GREISCH, 2002, p. 477). Sua saída deste panteísmo se fez através da inversão do pressuposto teológico hegeliano, o que o levou a reduzir a religião a uma "invenção do espírito humano, um produto da imaginação”. Segundo Greisch, esta inversão, que consiste em colocar a teologia hegeliana sobre seus pés antropológicos, foi assumida por uma série de pensadores para os quais a consciência humana se celebra a si mesma como fábrica de invenção de deuses.

Nietzsche pensa a crítica como genealogia, que se interroga sobre os valores em sua origem, e como interpretação, que oferece das coisas e dos acontecimentos tantos sentidos quanto os de seus intérpretes (GREISCH, 2002, p. 527). A genealogia e a interpretação estão também relacionadas com a linguagem, que, através das metáforas, mais que a realidade, mostram as intenções das relações das pessoas com as coisas. Daí a necessidade da suspeita, do questionamento e da desmistificação. Para ele, as religiões devem sua existência ao medo e às necessidades, às fraquezas e às perambulações da razão. Seu método o obriga a interrogar essa necessidade de crer, presente em todos os lugares, e está baseado num ateísmo, que o leva à declaração da morte de Deus, à crítica do cristianismo como moral dos fracos e a um niilismo.

Segundo Greisch, Kant funda a articulação entre razão teórica e razão prática numa filosofia da esperança, cuja origem é a doutrina reformada da justificação pela fé. O que ocorre quando essa "reserva teológica” desaparece, e a esperança é reclamada como algo ainda não realizado? É a isso, diz o filósofo 
luxemburguês, que se consagra Ernst Bloch, herdeiro de Feuerbach e, como ele, convencido de que a religião nada mais é que uma mera ilusão (GREISCH, 2002, p. 573). O filósofo alemão buscou interpretar os sonhos despertados pelo espírito humano, as manifestações da impaciência utópica que empurram a humanidade para a frente, mesmo suas manifestações religiosas, antropologizando a teologia no espírito da utopia.

A passagem por esses dois paradigmas é objeto de uma releitura no segundo capítulo do terceiro tomo da obra de Greisch, que busca sondar as potencialidades hermenêuticas e os obstáculos que cada um encerra (GREISCH, 2004, p. 161). Ele relê o paradigma especulativo à luz da representação e da figura. A análise, diz ele, permitiu passar do polo da intuição e do sentimento (Schleiermacher) ao da representação e do conceito (Hegel), antes de descobrir a importância da historicidade (Schelling, Rosenzweig e Rahner). Qual a dimensão hermenêutica desse paradigma? Confrontando Schleiermacher, Hegel e Rosenzweig, Greisch busca mostrar em que sentido a filosofia especulativa prepara o terreno à abordagem hermenêutica da religião. Contrapondo "restauração" (Schleiermacher) e "integração" (Hegel), ele mostra, em primeiro lugar, o esforço de Schleiermacher por construir uma "hermenêutica geral", que leva em conta o problema da linguagem e faz apelo a dois métodos complementares: o gramatical, voltado aos dados objetivos da língua, e o psicológico, interessado pelo uso que um autor fez do sistema de língua à sua disposição. Suas teses hermenêuticas influenciam sua teoria da religião e o levam a romper com a cisão, própria do iluminismo, entre hermenêutica geral e hermenêutica bíblica. O limite deste intento, observa Greisch citando Gadamer, é seu pressuposto, que é adivinhar o que se passa no íntimo do autor ou do locutor e, no caso da religião, no coração da alma crente.

A ideia hegeliana de mediação, baseada na perspectiva da integração, corrige, segundo Greisch, o intento de Schleiermacher. Trata-se, diz ele, seguindo Gadamer, de assumir o modo como funciona a consciência da história dos efeitos ou da influência, marcada pelo problema do reconhecimento da alteridade. A dialética do reconhecimento não se caracteriza somente pela interpretação 
especulativa da história, mas também da religião. Em todo o processo, "a vida do espírito [...] consiste em se reconhecer si mesmo na alteridade” (GREISCH, 2004, p. 179). O mérito de Hegel, diz o filósofo luxemburguês, foi ter compreendido a afinidade profunda que existe entre a representação (o figurativo) e o conceitual. É nesse sentido, diz ele, que Ricoeur define a hermenêutica do discurso religioso em diálogo com a filosofia hegeliana da religião: 1) trata-se de um processo circular que não cessa de partir do momento da experiência religiosa, evento de Palavra ou momento kerignático; 2) não cessa de gerar símbolos e interpretações deste imediato no seio de uma comunidade confessante e interpretante; 3) não cessa de visar ao pensamento conceitual, sem perder seu enraizamento na imediatidade inicial da religião nem das formas mediatizantes o pensamento figurativo (GREISCH, 2004, p. 182).

Em sua releitura do paradigma crítico, Greisch observa que os autores estudados oscilam entre ausência, própria aos que quiseram fazer frutificar os princípios do criticismo kantiano no terreno da filosofia da religião, e excesso, próprio aos que fazem da interpretação o único mestre da abordagem da religião, devorando o objeto que buscam interpretar (GREISCH, 2004, p. 193). Ele se pergunta se a razão crítica é inimiga da hermenêutica e defende a tese segundo a qual a razão hermenêutica só pode se constituir enfrentando simultaneamente os "mestres da crítica" (no sentido kantiano) e os "mestres da suspeita" (entendidos no sentido nietzcheano).

Apesar de o termo "hermenêutica" não figurar no vocabulário de Kant, a palavra "compreensão", que se tornou central no paradigma hermenêutico, é constitutiva de sua reflexão, que pode ser entendida como a expressão da “inquietude daquele que quer compreender sua própria compreensão”, inquietude que se revela em sua radicalidade quando afronta o problema do mal radical (GREISCH, 2004, p. 215). Nesse sentido, observa Greisch, a hermenêutica da religião deverá enfrentar a definição kantiana da religião, que, por um lado, lhe dá como tarefa restaurar no sujeito moral sua capacidade de agir segundo o dever, e, por outro, se desdobra no horizonte da terceira questão kantiana: o que me é 
permitido esperar? Vista neste sentido, a abordagem crítica não é estrangeira ao desejo de compreender hermenêutico.

Quanto às leituras antropológicas de Feuerbach, Nietzsche e Bloch, elas utilizam, segundo Greisch, um conceito forte de interpretação e lançam um desafio a toda hermenêutica da compreensão. As questões que elas levantam não são do mesmo gênero que as do criticismo kantiano, pois elas não se perguntam se a análise da religião supõe uma problemática hermenêutica, mas propõem um conceito hiperbólico de interpretação que parece destruir os objetos que estudam e a própria ideia de razão. Esta questão é crucial, pois, segundo Greisch, de um lado, ela liga Feuerbach e Bloch a Marx, e do outro, Freud a Nietzsche. A oposição nietzscheana entre Dionísio, que diz sim à vida, e o Deus Crucificado, que é uma maldição lançada sobre a vida, a afirmação feuerbachiana do homo religious como animal desejante, que não cessa de projetar sobre o mundo seus desejos, a releitura utópica do desejo em Bloch e a centralidade do desejo em Freud, são sintomas, de um "cogito ferido", que "não se possui a si mesmo, que só compreende sua verdade originária na e pela confissão da inadequação, da ilusão, da mentira da consciência atual" (GREISCH, 2004, p. 225). Ricoeur, que buscou pensar as contribuições dos mestres da "suspeita”, via nas oposições levantadas por eles, um apelo a lançar as bases de uma hermenêutica que ultrapassasse a pretensão da consciência se erigir em origem primeira do sentido. Em Soi-même comme un autre ele propõe uma hermenêutica do si que ultrapasse a antinomia entre um "si exaltado" cartesiano e um "si humilhado" nietzscheano. A suspeita não tem em vista somente o homo religious, mas o si. Paradoxalmente, observa Greisch, a filosofia hermenêutica encontra nos mestres da suspeita aliados e adversários. É necessário tornar as duas dimensões produtivas, e essa é a tarefa de uma filosofia hermenêutica.

\subsection{Os paradigmas fenomenológicos e analíticos do estudo da religião}

No segundo volume da Sarça ardente e as luzes da razão, Greisch continua sua pesquisa histórica e sistemática sobre a "invenção da filosofia da religião", voltando-se, não mais para os "herdeiros do século XIX", mas para a "cena 
contemporânea”, que começa a tomar forma nas duas primeiras décadas do século XX. Ele estuda, neste volume, a herança multiforme e complexa de E. Husserl (paradigma fenomenológico) e de L. Wittgenstein (paradigma analítico).

O paradigma fenomenológico reúne as filosofias da religião que seguem as pegadas da de E. Husserl. Greisch confere dois sentidos ao termo fenomenologia.: o sentido metodológico e descritivo, que caracteriza uma abordagem da experiência religiosa que prioriza a descrição sobre a explicação; o sentido husserliano, que repousa sobre três descobertas do fundador da fenomenologia: a intencionalidade como fato fundamental da consciência como tal (toda consciência é consciência de alguma coisa); a intuição categorial (que, diferentemente de Kant, não é limitada à experiência sensível); o a priori. A essas descobertas, há que acrescentar o método da redução (epoché). A ideia de doação, afirma Greisch, é a que define o princípio dos princípios da fenomenologia husserliana (GREISCH, 2002, p. 65-67). Esse paradigma constitui a espinha dorsal da obra de Greisch e está articulado em cinco capítulos: E. Husserl, R. Otto, M. Scheler, os fundadores das ciências da religião, os novos horizontes da fenomenologia atual.

A máxima que guiou a pesquisa husserliana é, segundo Greisch, "ir às coisas mesmas”. As coisas mesmas, às quais Husserl queria voltar, nada mais são que os atos intencionais da consciência, fonte primeira de toda significação (GREISCH, 2002b, p. 21). Esse retorno às coisas mesmas implica uma atitude particular: escutar a voz dos fenômenos. Para isso, Husserl elaborou o método da redução (epoché), que é uma ruptura radical com a "atitude natural”, sob todas as suas formas, no intuito de chegar à doação mesma das coisas. Apesar de não elaborar uma filosofia da religião, o postulado de base da fenomenologia o levou a afirmar que os fenômenos religiosos constituem uma região sui generis de significação e correspondem a um tipo fundamental de consciência originária (GREISCH, 2002b, p. 41). O acesso a esta região se dá através da redução, que consiste em pôr entre parênteses toda afirmação ou negação da existência de Deus, como de todo saber positivo prévio sobre ele tirado da teologia dogmática, da exegese ou das ciências da religião. Também para a religião se trata de ir às coisas mesmas. 
A categoria do "sagrado", proposta por R. Otto para dizer o sentido original da religião, contrapõe-se às categorias "totem”, "tabu”, “mana”, entre outras, elaboradas, no final do século XIX, por cientistas da religião e filósofos, como primeira experiência religiosa da humanidade. Para Otto, tais categorias passam ao lado do "fenômeno originário": o sentimento do numinoso. A religião não começa como uma religião, mas com o sensus numinis, o vivido do que é misterioso, a busca e a atração do mistério, um vivido que faz irrupção como o "sentimento do totalmente Outro nas profundezas da vida afetiva sob a influência de estímulos vindos do exterior (GREISCH, 2002b, p. 81). O sagrado provoca os sentimentos do "tremendum" e do "fascinorum", causando, por um lado, terror, pois é intocável (origem do interdito e do tabu), é inefável, é inacessível, é incompreensível, é não familiar e invulnerável, e, por outro lado, atrai.

Influenciado por Husserl, M. Scheler foi quem deu à filosofia da religião sua cidadania. Sua reflexão sobre a ética o levou a se interessar pela religião que, segundo ele, tem em si mesma seu fundamento, embora seus valores tenham afinidades com os da moral. Ele propõe uma tipologia sobre os dois tipos de sistemas filosóficos e religiosos. O identitário, que se apresenta sob as formas da "gnose" e do "tradicionalismo" e o dualista, que diferencia o ato religioso e o ato metafísico. Para ele, a saída é um sistema de conformidade, que respeita a autonomia integral dos domínios e possibilita a convergência no nível do objeto visado, conferindo à "consciência religiosa uma racionalidade intuitiva imediata" (GREISCH, 2002b, p. 127). Scheler analisa ainda a religião sob três vertentes: a objetiva, que realiza a descrição ôntica da essência do divino; a subjetiva, que busca a descrição eidética do ato religioso. Entre as duas vertentes se situa a análise das formas de manifestação próprias ao objeto religioso.

A história da religião, através dos trabalhos de F. Heiler, J. Wach, G. van der Leeuw e M. Eliade, que utilizam, direta ou indiretamente, os princípios do método fenomenológico da tradição husserliana, é objeto de um capítulo da obra de Greisch. De F. Heiler ele retoma alguns elementos do método da ciência da religião: o comparatismo, o conhecimento das línguas, a necessidade de frequentar 
os cultos da religião estudada, o alcance universal, a necessidade de passar da multiplicidade dos fenômenos à essência da religião. De J. Wach, ele valoriza o fato de ter sido o primeiro a elaborar uma obra sistemática de epistemologia das ciências da religião, disciplina descritiva, que recorre à fenomenologia, à história, à psicologia e à sociologia (GREISCH, 2002b, p. 182). De Van der Leeuw, ele valoriza a elaboração de uma fenomenologia voltada para as dimensões constitutivas do fenômeno religioso: o objeto e o sujeito da religião, os aspectos externos (o agir cultual) e internos (a experiência e as atitudes religiosas) da correlação do objeto e do sujeito, a visão religiosa do mundo, a pluralidade de religiões. Em Eliade ele percebe o apogeu da tradição fenomenológica, voltada, nos estudos do estudioso romeno, à elaboração de uma morfologia geral da religião (GREISCH, 2002b, p. 219).

Os autores da "idade de ouro" da fenomenologia da religião se contentam, segundo Greisch, em aplicar a "técnica fenomenológica” aos fenômenos religiosos sem se preocupar com os pressupostos filosóficos do método fenomenológico (GREISCH, 2002b, p. 241), o que não é mais o caso dos filósofos franceses estudados por ele: E. Levinas, J.-L. Chétien, J.-Y. Lacoste, J.-L. Marion, M. Henry. A reflexão de Levinas sobre a oração a situa ao lado do chamado ao socorro, à ajuda, dirigida a outrem. $\mathrm{O}$ ato de pedir ou de orar é o eco de um pensamento mais antigo que o da constituição de um saber, pois coloca frente a um rosto, que põe o sujeito no acusativo e o coloca radicalmente em questão (GREISCH, 2002b, p. 244). O pedido originário não tem sua fonte no eu, mas no outro, e pressupõe um Deus invisível, infinito, que nenhuma relação esgota, mas que introduz ao "regime do a Deus". J.-L. Chrétien elabora uma fenomenologia da "voz nua", crítica das filosofias da presença e aberta ao dom da palavra. Sua pesquisa o torna sensível às modalidades da vigilância, da atenção e da responsabilidade, próprias à voz nua, e que o leva também a pensar o fenômeno da oração, que para ele é o fenômeno religioso por excelência (GREISCH, 2002b, p. 254). J.-Y. Lacoste elabora uma fenomenologia da liturgia, na qual o futuro absoluto da redenção vem à ideia (GREISCH, 2002b, p. 267). J.-L. Marion, intérprete de Descartes, retoma a distinção entre ídolo e ícone, e mostra que a morte de Deus, proclamada por 
Nietzsche, refere-se a um conceito idolátrico de Deus. A única figura que põe freio ao império dos ídolos é o ícone, pois afasta da lógica da representação e leva a reconhecer uma distância que não se pode abolir (GREISCH, 2002b, p. 309). Para M. Henry, a fenomenologia, ao fazer da intencionalidade seu único fio condutor, não elucidou a essência da fenomenalidade enquanto tal (GREISCH, 2002b, p. 335).

O paradigma analítico tem em Wittgenstein sua referência. De fato, dos três capítulos consagrados a este paradigma na obra de Greisch, dois são dedicados à obra de Wittgenstein.

Segundo Greisch, em sua primeira grande obra, o Tractatus, Wittgenstein mostra os desafios filosóficos das línguas formais, que comprovaram sua eficácia na lógica e na matemática. Nesta ótica, o filósofo austríaco observa que a análise deve remontar às proposições elementares, logicamente simples, que obrigam a traçar uma fronteira nítida entre as proposições dotadas de sentido, pois enunciam estados de coisas ou tautologias lógicas, e as proposições que não dizem nada. No final do Tractatus, que abre espaço à mística, o filósofo luxemburguês acredita poder encontrar uma filosofia da religião em germe. O elemento místico, diz ele, corresponde, em Wittgenstein, ao sentimento do mundo como totalidade fechada (GREISCH, 2002b, p. 411). Greisch se pergunta, porém, qual o significado do fazer silêncio com o qual termina o Tractatus. Para ele, o que não se pode dizer, deve somente ser mostrado.

O capítulo consagrado aos herdeiros do empirismo clássico estuda as contribuições de W. James aos estudos da religião. Segundo Greisch, sua obra sobre a experiência religiosa faz dele um dos grandes pioneiros de uma nova abordagem empírica e pragmática da religião. Vinte anos mais tarde, porém, o próprio empirismo muda radicalmente sob o choque da recepção do Tractatus de Wittgenstein. Os representantes do "círculo de Viena" buscam estabelecer um pacto entre o empirismo tradicional e as exigências de rigor, próprias à análise lógica. As incidências do empirismo lógico concernem, sobretudo, os debates ao 
redor do princípio de verificação. Suas diferentes formulações tornavam problemática toda justificação dos enunciados religiosos. Apesar disso, vários estudiosos avançaram sobre o terreno de uma filosofia analítica da religião. Para os que aceitavam a versão forte do critério, a tarefa era mostrar que, contrariamente às aparências, os enunciados religiosos podem se conformar ao princípio de verificação. Para os que não aceitavam o critério, a opção era destruí-lo. Wittgenstein, em 1929, efetua, porém, uma reviravolta radical em sua perspectiva inicial, com o acento posto na linguagem ordinária e na complexidade dos jogos de linguagem, eles mesmos inseparáveis de um certo número de formas de vida. Esta nova orientação, presente nas Investigações filosóficas, é uma espécie de fenomenalismo linguístico, que contrasta com o atomismo e o empirismo lógico. Ela se revela fecunda para a análise da linguagem religiosa, como se pode ver a partir dos anos 60, quando se multiplicaram filósofos da religião inspirados na teoria dos jogos de linguagem, que buscam descrever a gramática própria do discurso religioso.

$\mathrm{Na}$ releitura do paradigma fenomenológico, Greisch se pergunta em que ele conduz a uma problemática hermenêutica. Segundo ele, os autores estudados não entendem do mesmo modo a fenomenologia e é impossível uma visão de conjunto do que pensam sobre essa questão. Ele propõe sua releitura do paradigma fenomenológico ao redor de três questões. A primeira o leva a se perguntar se a hermenêutica constitui um corpo estranho para a maneira como Husserl quis "salvar os fenômenos", corpo que a verdadeira fenomenologia deve rejeitar, como o fez o fundador da fenomenologia com as teses de Heidegger. Ele se interroga também sobre o enxerto da hermenêutica sobre a fenomenologia, proposto por Ricoeur, e mostra as possiblidades desse enxerto. A segunda questão decorre das análises dos trabalhos de Heiler, Wach, Van der Leew e Eliade, autores que defendem uma concepção da fenomenologia próxima à hermenêutica de Dilthey e à fenomenologia de Husserl. Para Greisch, é possível reconhecer nesses autores a expressão de um enxerto bem realizado entre fenomenologia e hermenêutica. Apesar de haver consenso sobre o trabalho deles, há que assinalar que eles obrigam a levar em conta esse terceiro parceiro da conversação triangular entre 
fenomenologia e hermenêutica, que são as ciências da religião. A última questão decorre das questões levantadas pelas orientações da fenomenologia das últimas décadas, que pretendem sua refundação, mas voltando as costas às ciências humanas em geral e às ciências da religião em particular. Somos obrigados, diz Greisch, a nos perguntar em que a ideia de doação, de Marion, e a ideia de autoafecção, de M. Henry, rimam ou não com uma hermenêutica da compreensão e da interpretação (GREISCH, 2004, p. 241).

Com relação ao paradigma analítico, Greisch começa mostrando as dificuldades de estabelecer o diálogo entre a razão hermenêutica e a razão analítica. Um simples olhar sobre o funcionamento das instituições universitárias, diz ele, mostra que se trata de duas tribos filosóficas distintas, que não têm o hábito de se frequentar. Pode-se concluir daí que elas têm interesse em se manter isoladas, pois se trata de dois tipos de racionalidade, um que faz da intencionalidade a matriz última de toda doação de sentido, e o outro que se sustenta sobre o uso efetivo dos signos e da linguagem (GREISCH, 2004, p. 328)? O autor cita Wittgenstein, que afirma que o autêntico filósofo não é membro de uma "paróquia de pensamento" e defende a tese segundo a qual a imagem do "enxerto", utilizada para a relação entre hermenêutica e fenomenologia, pode ser transferida às relações do paradigma analítico com o hermenêutico.

\section{Um paradigma hermenêutico da religião}

O terceiro tomo da Sarça ardente e as luzes da razão estuda o paradigma hermenêutico, que é o do próprio Greisch. A obra está organizada em 5 capítulos. No primeiro, o autor propõe uma breve história da hermenêutica. Em seguida, estabelece um diálogo entre os elementos desse paradigma e os dos quatro precedentes. No terceiro capítulo, ele recolhe as contribuições de autores que, como ele, são “filósofos da passagem” (H. Bergson, J. Nabert, K. Jaspers), tratando, nos dois últimos capítulos, as contribuições de Heidegger e Ricoeur à filosofia da religião. É impossível captar, num espaço tão curto, a riqueza da leitura das 
análises de Greisch sobre os representantes desse paradigma. É através delas que se delineia sua própria perspectiva.

Greisch inicia seu estudo do paradigma hermenêutico apresentando os quatro campos de investigação que estão em sua origem: 1) o da linguagem da adivinhação, 2) o da discussão do estatuto do texto sagrado, 3) o do projeto de uma crítica da razão histórica, proposto por Dilthey, o do lugar da tradição na compreensão do fenômeno religioso, levantado por Gadamer.

O primeiro campo abordado por Greisch é o da arte da adivinhação. Referindo-se ao oráculo de Delfos, ele se pergunta se o prestígio social, do qual ele gozava na Grécia, não era uma das razões que levou Platão, no diálogo Íon, a se interessar por esse problema. O fato de a adivinhação constituir um fenômeno religioso, diz ele, merece a atenção do fenomenólogo da religião. Van der Leeuw já havia visto isso, no parágrafo 54 de sua Fenomenologia da religião, no qual diz que, em seu sentido religioso, a palavra oracular equivale a uma "consulta" ao poder do numinoso. Essa palavra permite determinar os tempos "fastos" e "nefastos", que contribuem para realizar com sucesso certas ações perigosas. O que está em jogo, diz Greisch, não é prever o futuro, mas determinar a ocasião favorável ou desfavorável. A adivinhação é mais que satisfazer uma curiosidade, mais que a certeza do sucesso. Ela reflete a consciência aguda de que não se pode dar um único passo na vida sem conhecer a ocasião, sem saber se, agindo dessa ou daquela maneira, "as potências estão sendo postas em movimento" (GREISCH, 2004, p. 20).

A busca de domínio do acaso representa um estado arcaico da contingência. Mesmo se a determinação das circunstâncias favoráveis frequentemente recorra ao transe e ao êxtase, a necessidade de se interpretar os oráculos e o fato de que a consulta não se dar de qualquer forma, confere à arte da adivinhação o ar de uma verdadeira ciência, que requer um corpo de intérpretes qualificados. No oráculo de Delfos, diz Greisch citando Van der Leeuw, "qualquer que seja o método de interrogação do oráculo, ele só dará uma autêntica instrução através da 
interpretação. A Pítia podia divagar, mas seus exegetas ou seus 'teólogos' eram suficientemente razoáveis" (GREISCH, 2004, p. 21). O mesmo se pode dizer dos cultos de possessão, que necessitam ao menos de um "teólogo" que seja capaz de discernir qual deus possui a alma do fiel, quando este está submetido ao transe. Segundo o filósofo luxemburguês, as práticas de adivinhação continuam vivas hoje, mesmo em sociedades ditas secularizadas, onde muitos chefes de estado e pessoas responsáveis por decisões políticas e econômicas, recorrem aos serviços de adivinhos.

De fato, observa Greisch, por toda parte, em todas as culturas, há certa percepção de que os deuses enviam sinais à humanidade, e sua compreensão nunca é evidente. A história comparada das religiões mostra que as práticas de adivinhação existiram nas grandes civilizações. $\mathrm{O}$ que resta do discurso religioso se lhes são retirados os oráculos e as profecias? O autor é consciente das múltiplas expressões da arte da adivinhação, mostrando como, na China e na Grécia antiga, ela esteve relacionada com a filosofia. Na China, o acesso à realidade privilegia as relações entre conhecimento e ação, onde as distintas coisas convivem numa rede de relações. A adivinhação joga aí um papel capital. Não se trata de uma interrogação sobre o desconhecido, mas sobre um domínio balizado de antemão, donde o caráter ritual e não profético dos oráculos, que tornavam possível uma abordagem racional do universo. O Livro das mutações é a melhor expressão desta tentativa de racionalizar as técnicas de adivinhação, tornando-se o livro fundamental da filosofia chinesa, ao qual todos os pensadores se referiam (GREISCH, 2004, p. 28-29). Na Grécia antiga também a palavra jogava um papel determinante na prática da adivinhação. Tratava-se de uma maneira distinta de entender a racionalidade. A sacerdotisa que proferia oráculos em Delfos necessitava de intérpretes. Essa forma religiosa já exigia interpretação, mas ao pensá-la filosoficamente, Platão viu nela uma espécie de "irracionalidade" ou "loucura" divina, que necessitava ser "racionalizada" para poder integrar-se nos crentes que habitavam a polis. Para o filósofo luxemburguês, a via desta racionalização passava pela hermenêutica, embora Platão lhe negasse o título de 
“episteme" e de "techne". O estar na polis, interpelava, porém, os praticantes do logos filosófico (GREISCH, 2004, p. 30-31).

O segundo campo da investigação de Greisch tem a ver com o estatuto do texto sagrado e das práticas de leitura e de interpretação desenvolvidas pelas comunidades religiosas que o reconhecem como texto fundador. Para os fenomenólogos da religião, recorda o autor, mais que apanágio das religiões do Livro, a categoria "texto sagrado" é constitutiva do fenômeno religioso. As práticas de leitura e interpretação desses textos, desenvolvidas em muitas religiões, levantam questões que a filosofia da religião não pode ignorar (GREISCH, 2004, p. 36). Para o filósofo luxemburguês, a questão decisiva é saber que sorte a hermenêutica, que se pretende ao mesmo tempo geral e filosófica, pode reservar às hermenêuticas particulares? Este problema não diz respeito apenas à hermenêutica bíblica, mas também à literária. É possível colocar num mesmo patamar textos com uma pretensão normativa, como os de origem jurídica e religiosa, e os que não possuem essa pretensão, como os das obras literárias? Aqui se encontra, sem dúvida, uma diferença importante entre uma hermenêutica teológica, cuja pretensão em geral é normativa, e uma hermenêutica literária, que está ao serviço da ampliação do sentido dos textos. Aqui se encontra igualmente a diferença entre a hermenêutica que é feita pela exegese bíblica, própria à teologia, e a das abordagens históricas, feita pelas ciências da religião.

A partir do momento em que se desenvolve uma hermenêutica geral, observa Greisch, não se pode ignorar a questão de sua relação com as hermenêuticas "especiais", das quais fazem parte as "Sagradas Escrituras". Como justificar a autoridade de um texto no qual o crente descobre a "Palavra de Deus", e que ele considera como "inspirado"? Se a Escritura é um livro humano, que deve ser lido com os olhos humanos, pode ela, ao mesmo tempo, reivindicar ser a Palavra de Deus? Segundo o autor, esse problema, vasto e complexo, deixou vestígios consideráveis na história da hermenêutica. Partindo da história da interpretação da Escritura Sagrada do cristianismo, Greisch se focaliza em quatro articulações importantes, que, para ele, constituem a base da filosofia da religião: 1) 
o primeiro momento corresponde à teoria do quádruplo sentido das Escrituras (literal, alegórico, moral ou tropológico, anagógico), que teve em Orígenes sua primeira expressão teórica. Apesar de ser menosprezada pela hermenêutica moderna, o autor a considera importante para a ideia de razão hermenêutica e para uma filosofia da religião (GREISCH, 2004, p. 53-66); 2) o segundo momento é o da crise da Reforma e do debate que opôs Lutero e Erasmo. Trata-se do Sola Scriptura de Lutero e do postulado que faz da Escritura seu próprio intérprete. Esse momento marca o início da hermenêutica moderna. Em contraponto a esta visão, os humanistas, como Erasmo, evidenciam as obscuridades do texto bíblico, e os defensores católicos da Tradição, como Belarmino, assumem a crítica dos humanistas (GREISCH, 2004, p. 69-78); 3) o terceiro momento é representado por Louis Meyer e Baruch Spinoza, dois autores cujas existências são inseparáveis, pois o primeiro, médico de Spinoza, escreveu um livro anônimo que fez muito ruído: $A$ filosofia intérprete da Sagrada Escritura, primeira tentativa de aplicar os princípios da filosofia cartesiana à hermenêutica bíblica. Quatro anos depois Spinoza publicou seu Tratado teológico-político, que constitui sua primeira tomada de posição pública relativa à religião e à política. As duas obras suscitaram vivas reações e condenações. A partir delas, diz Greisch, se levanta a questão: sob quais condições os filósofos podem se arriscar a uma interpretação da Sagrada Escritura, uma vez que as comunidades religiosas a consideram seu texto sagrado? Para os dois autores, observa o filósofo luxemburguês, a Escritura só é "sarça ardente" se for esclarecida pela luz da razão cartesiana, já que em si mesma nada mais é que uma "simples sarça com espinhos filológicos" (GREISCH, 2004, p. 7998); 4) o quarto momento é o do pietismo e a tríplice sutilidade da arte de interpretar que ele propõe: compreensão (subtilitas intelligendi), interpretação explicitante (subtilitas explicandi), aplicação (subtilitas applicandi). Daí deriva, segundo Greisch, a questão da relação entre compreensão e aplicação. Esta última, em geral periférica, é, porém, constitutiva da compreensão. Para os pietistas, a sarça ardente não se encontra no texto, mas na alma do fiel, abrasada pelo amor das coisas divinas que lhe inspira o Espírito de Deus. É contra esta exaltação pietista, diz Greisch, que se levanta o iluminismo (GREISCH, 2004, p. 100-109). 
No terceiro campo de investigação, Greisch dialoga com os inícios da hermenêutica moderna (GREISCH, 2004, p. 110-132). Segundo ele, no começo do século XIX, com Friedrich August Wolf, Friedrich Ast, Friedrich Schlegel e Friedrich Schleiermacher, o acento se desloca cada vez mais na direção da compreensão, de seus pressupostos, suas dificuldades e questões. Este novo paradigma tornou possível o nascimento de uma verdadeira filosofia hermenêutica, que tem em Wilhelm Dilthey o pioneiro. De fato, os discípulos imediatos de Schleiermacher não fizeram frutificar suas intuições hermenêuticas. Dilthey foi quem retomou o projeto, abrindo todas as portas da filosofia à hermenêutica. Ele o fez numa conjuntura epistemológica e filosófica inédita. As primeiras décadas do século XIX viram emergir um novo "continente epistemológico": o das ciências do espírito, cuja primeira grande expressão era a historiografia, à qual se acrescentaram a economia política, as ciências jurídicas e políticas, as ciências da religião, o estudo da literatura e da poesia, das artes plásticas e da música, a psicologia. Dilthey recebeu dos grandes mestres da escola histórica de Berlim sua primeira formação universitária. Enquanto seus mestres tiveram que renunciar à filosofia especulativa da história de Hegel, ele representa uma nova geração, não tentada pelo hegelianismo, mas pelo positivismo. Permanece nele, porém, o desejo de compreender o devir histórico. Alguns autores da época advogavam a necessidade de um novo Kant, que levasse à descoberta do imperativo categórico da história como fonte da vida histórica. Dilthey foi movido a "compreender a vida a partir dela mesma", a "penetrar sempre mais profundamente no mundo histórico”. O desejo insaciável de captar o mundo histórico é a expressão da própria vida em sua diversidade e profundidade. Segundo Greisch, isso o conduziu a se interessar de perto pelas ciências do espírito e a se interrogar sobre a possível "fundação do conhecimento do mundo espiritual, que é o que faz emergir o próprio mundo". Em seu intento de "fundar" as ciências do espírito, o filósofo alemão fez a distinção entre explicar, próprio às ciências naturais, e compreender, específico às ciências do espírito.

Ele se interessou também pela questão da religião, retomando, em parte, a definição de Schleiermacher da religião como sentimento de dependência absoluta. 
Para Dilthey, a religião deve ser buscada nas intuições e sentimentos que o universo suscita no ser humano. São os vividos religiosos que fornecem os princípios que permitem explicar a diversidade das religiões e os critérios para se pronunciar sobre sua validade. Para ele, os vividos íntimos da alma religiosa, e não o testemunho da Escritura, é a instância última da verdade religiosa. O sujeito religioso adota uma atitude própria para com o mundo, que deve ser entendida a partir de seus próprios critérios e não dos de outros campos da experiência. Para ele, há uma experiência religiosa que age legitimamente, de modo autônomo, originário e indestrutível na vida da alma e é esta experiência a origem dos dogmas, das cerimônias e das organizações religiosas. Esse vivido interior se expressa em exteriorizações da vida enquanto expressão compreendida. São essas exteriorizações fixadas da vida, seus efeitos sobre outros, que informam o ser humano sobre si mesmo e o levam a se conhecer pela compreensão. A leitura filosófica dos fenômenos religiosos deve percorrer as objetivações da vida religiosa, inscritas em textos, ritos, práticas religiosas, costumes, estilos de vida etc. É partindo dessas objetivações que ela pode encontrar os vividos que lhe deram nascimento. A religião ocupa, segundo Dilthey, um lugar particular e central no seio dos vividos que fundam as objetivações e as organizações do espírito no mundo.

O quarto campo de investigação é o da hermenêutica de Gadamer, que, segundo Greisch, não elaborou uma filosofia da religião. Em Verdade e método, o conceito de razão hermenêutica atinge sua plena maturidade filosófica. Crítico de Dilthey, ele busca captar as experiências de verdade que não se enquadram no ideal cartesiano de método: arte, linguagem e história. Embora a religião não figure entre essas experiências, Greisch pensa que ela joga um papel exemplar em Gadamer. Em Kant, diz o filósofo luxemburguês, não se pode levantar a questão da verdade com relação à arte, pois nela domina o prazer estético. Esse pressuposto tornou, porém, possível o conceito de experiência vivida (Erlebnis), que ganhou importância na literatura e na religião, pois busca captar o vivido íntimo do sujeito. Mas esse vivido muda de sentido a partir do momento em que a consciência acentua a distância que a separa das tradições vivas que deram origem às obras 
culturais. Em Dilthey, compreender significava reencontrar os vividos originais que produziram essas objetivações da vida (GREISCH, 2004, p. 137). Gadamer põe em evidência os limites do vivido artístico e fornece uma reflexão crítica sobre os limites do vivido no campo da religião. A autenticidade das experiências religiosas exige outros critérios de juízo que a intensidade dos vividos, pois tais experiências não se reduzem a suscitar emoções, como o sensus numinis, o sentimento de dependência absoluta, o fervor etc.

O estudo de Gadamer sobre o vivido estético, que ajuda a entender o vivido religioso, é completado com seu estudo sobre a literatura. Diferente das outras artes, diz ele, alguns acham que a leitura conduz a um prazer solitário, que aliena o leitor do mundo. Contra esta concepção, ele lembra que a literatura foi inventada para ser declamada por rapsodos, e isso significa que ela só existe no ato de ler, seja em público, seja em privado, pois ela implica um trabalho de compreensão no qual o "verbo interior" joga um papel central. Além do mais, ela está ao serviço da transmissão de uma herança espiritual, consignada nos "clássicos" da "literatura mundial". Para o filósofo alemão, é “clássica” uma obra que pode ser lida por todo mundo, independente da distância temporal que a separa de seus novos leitores. Os clássicos permanecem falantes, mesmo que o mundo ao qual se dirige seja outro. $\mathrm{O}$ milagre de sua compreensão é a ressurreição do sentido que surge do túmulo da letra. Em sua decifração e interpretação acontece a transformação de algo estranho e morto em algo presente e familiar (GREISCH, 2004, p. 143).

Na parte central de Verdade e método, sublinha Greisch, Gadamer estende o conceito ontológico de verdade ao conjunto das ciências do espírito, rompendo com a orientação epistemológica de Schleiermacher e Dilthey. Para o filósofo alemão, graças à interpretação transcendental da compreensão, proposta por Heidegger, o problema hermenêutico ganha um alcance universal e uma nova dimensão, expressos nos seguintes conceitos: "pertença do intérprete a seu objeto”, "estrutura projetiva do compreender”, “trabalho de apropriação”, "historicidade do compreender", "pré-compreensão". Segundo o autor de Verdade e método, a suspeita contra o “preconceito” ou a “pré-compreensão”, é um preconceito do 
iluminismo, que elimina o poder da tradição. Ao resgatar as noções de preconceito, autoridade e tradição, ele reconhece a pertença do ser humano à história, através da língua, da família, da sociedade etc. Gadamer introduz então uma de suas teses mais importantes para a hermenêutica: a da distância histórica, segundo a qual é preciso reconhecer na distância temporal uma possibilidade positiva e produtora da compreensão, não um abismo aberto, mas preenchido, graças à continuidade de proveniência e de transmissão. Aplicado à religião, esse princípio, pode, segundo Greisch, ser assim entendido: “o acontecimento pode se tornar advento, pois, ao tomar tempo, ele ganha sentido" (GREISCH, 2004, p. 147). O conceito de distância temporal levou ainda o autor de Verdade e método a elaborar duas outras noções: a de "fusão de horizontes" e a de "história dos efeitos". A primeira mostra que o processo de interpretação é o resultado do encontro entre o horizonte do texto a ser interpretado e o horizonte de seu intérprete, que faz com que cada interpretação faz “aumentar” o significado do texto. A segunda noção valoriza os efeitos desse encontro no próprio processo de interpretação, ou seja, a leitura produz uma tradição de leitura.

A arte de compreender e a arte de questionar supõem a capacidade de criar uma linguagem comum. Esta tese leva Gadamer a afirmar que se entender no diálogo não é fazer triunfar o próprio ponto de vista, mas sofrer uma metamorfose, que visa a introduzir no que é comum e faz com que ninguém permaneça como era antes do diálogo. A linguagem, diz ele, é o meio universal no qual se opera a compreensão, que se realiza na interpretação explicitante.

Greisch se pergunta pelo interesse dessas teses para a filosofia da religião. Retomando a frase “o diálogo que somos”, do autor de Verdade e método, ele afirma que a experiência não é o que fazemos, mas o que nos acontece e nos transforma. Ora, nossas experiências são múltiplas e impossíveis de serem reconduzidas à unidade do saber. Isso vale também para os nomes inventados pelos humanos para se relacionar com o divino. Essas experiências múltiplas e suas numerosas apelações do divino são consignadas em tradições que nos precedem e continuam a determinar nosso ser. Entendida como diálogo, a linguagem constitui 
nosso próprio ser. Ora, falar supõe a capacidade de escutar. Ao atribuir à experiência hermenêutica a mesma universalidade que a língua e a razão, Gadamer introduz a ideia de uma verdade hermenêutica, que seria o desafio de todos os jogos de compreensão (GREISCH, 2004, p. 152).

Além desses momentos constitutivos do paradigma hermenêutico, Greisch, como acima foi assinalado, o põe em diálogo com os demais paradigmas e apresenta alguns autores responsáveis pela passagem ao paradigma hermenêutico. Ele dedica ainda dois capítulos a dois grandes representantes da hermenêutica contemporânea: M. Heidegger e P. Ricoeur. O presente texto fará breves considerações sobre esses autores, antes de retomar as conclusões de Greisch.

Greisch examina o percurso de Heidegger em cinco passos: 1) os dos ensinamentos em Freibourg (1919-1923), cujo centro de gravidade são os cursos sobre as epístolas de Paulo aos Gálatas, as Confissões de Agostinho e a mística medieval, nos quais o filósofo alemão esboça os lineamentos de uma interpretação da vida religiosa, que estão na origem da elaboração de sua "hermenêutica da vida fática"; 2) o dos ensinamentos dispensados em Marbourg (1924-1928), que correspondem à redação de Ser e tempo (1927), onde Heidegger afina a ideia da analítica do Dasein. Os textos desta época não dizem quase nada sobre os fenômenos religiosos; 3) o dos anos 1928-1934, quando Heidegger se esforça por lançar as bases de uma metafísica do Dasein no prolongamento do esboço de uma ontologia fundamental sobre a qual terminava Ser e tempo; 4) os da época da "virada", de 1936, data a partir da qual se impôs a Heidegger a necessidade de inventar um dizer e um pensar adequado à verdade do ser. Ele se inspira então nos hinos de Hölderlin para propor uma nova interpretação do sagrado e evoca a figura do "último deus" ou do "deus último", que constitui uma alternativa ao deus causa sui da onto-teologia. Em sua entrevista de 1969 a Der Spiegel, recorda Greisch, Heidegger declarou: "só um Deus pode ainda nos salvar". Trata-se, diz o filósofo luxemburguês, de uma profissão de fé que reenvia diretamente ao "último deus” de seus escritos, que podem ser declarados esotéricos, pois foram publicados após sua morte. Greisch se pergunta, como determinar a relação desse deus com o deus da fé 
religiosa, diante do qual se pode ajoelhar para rezar, ao qual são apresentadas ofertas e para quem se cantam hinos de louvor e de ação de graças?; 5) o dos textos tardios, nos quais Heidegger afronta a questão do mal através da noção de "perigo", embora não se refira à questão de Kant sobre o mal radical. Ora, diz Greisch, essa questão subjaz à hermenêutica kantiana da esperança e é a única maneira de acolher a religião nos limites da simples razão. A análise heideggeriana do mal ajuda a entender o que a filosofia da religião pode ensinar à escola heideggeriana e as razões que impediram Heidegger de continuar seu intento inicial de pôr os fundamentos de uma autêntica fenomenologia hermenêutica da religião.

Ricoeur é o principal interlocutor de Greisch em sua busca do paradigma hermenêutico do estudo da religião. A riqueza de sua contribuição é retomada a partir da categoria "elipse hermenêutica". Com relação aos temas, eles são reunidos ao redor da pergunta kantiana: “o que me é permitido esperar?” A aposta de respeitar indefinidamente a verdade do outro constitui o fio condutor da leitura das várias elipses que o filósofo luxemburguês encontra em Ricoeur.

Com relação às "elipses", Greisch assinala inicialmente as de caráter existencial, que têm a ver com a biografia de Ricoeur, dando destaque para os pares inquietude e curiosidade, crítica e convicção, e as de caráter metodológico, como o par explicar e compreender, herdado de Dilthey. A relação entre esses pares não é a da síntese, de tipo hegeliano, mas a da possibilidade de que "o que a linguagem escatológica chama de esperança seja recuperado reflexivamente no adiamento de toda síntese" (GREISH, 2004, p. 737). Greisch recorda também a versão ricoeuriana do círculo hermenêuticos: "crer para compreender, compreender para crer" e apresenta os grandes momentos da construção da hermenêutica do filósofo francês: 1) o da hermenêutica dos símbolos (anos 60', inicialmente marcado pela fenomenologia, com a obra Le volontaire et l'involontaire, que vê a passagem da fenomenologia à hermenêutica, nas obras L'homme faillible e La symbolique du mal, obras que retomam a problemática do mal e a inscreve no horizonte da esperança; 2) o da hermenêutica dos textos (anos 70 e 80'), com obras de caráter mais metodológico, que estabelecem um rico diálogo com o estruturalismo, a 
filosofia da linguagem e as teorias literárias; 3) a abertura da hermenêutica aos problemas da filosofia prática (anos 9o'), que, sobretudo na obra Soi-même comme um autre, leva à elaboração de uma perspectiva narrativa da identidade e da ética, dando origem à noção de "homem capaz", responsável por suas ações de caráter moral e interlocutor a quem é dirigida a revelação divina.

\section{Conclusão: contribuições e limites dos estudos de Greisch sobre a religião}

A obra de Greisch, como foi assinalado no início deste estudo, é de caráter abrangente, privilegiando, sobretudo, abordagens de autores de língua alemã, francesa e inglesa. Que contribuições ela poderia dar ao conjunto de estudos sobre a religião em curso no Brasil? Aparentemente, pelos conteúdos acima apresentados, o autor se contenta em oferecer uma visão dos autores representativos de cada paradigma, não propondo uma perspectiva própria. Nas considerações finais propostas a seguir, serão indicadas as contribuições próprias a este tipo de abordagem, como também o que parecem ser seus limites para o estudo da religião no Brasil.

O enfoque proposto por Greisch é o da filosofia da religião, delineando bem seu ponto de vista e, aparentemente, deixando de lado a enorme contribuição das outras disciplinas que constituem o imenso campo dos estudos da religião. Porém, como foi mostrado ao longo desse texto, vários representantes dessas disciplinas são estudados por ele, como seu aporte para o estudo e a compreensão do fenômeno religioso. A chave de leitura dos paradigmas é bastante fecunda, pois permite uma certa classificação, que pode ser questionada, mas que tem sua razão de ser e indica o eixo condutor dos autores e estudos representativos do paradigma em questão.

No Brasil, muitos estudos sobre fenômenos religiosos importantes foram realizados no decorrer do último século: os de caráter histórico, sobre o catolicismo, o protestantismo e o pentecostalismo; os de caráter sociológico ou psicológico, sobretudo sobre as religiões de matriz africana; os de caráter 
etnológico, sobre as religiões indígenas; os de caráter teológico, que privilegiam as várias tradições religiosas presentes no país. Boa parte do aparato conceitual e metodológico desses estudos é inspirada nos clássicos dos estudos da religião de origem europeia ou norte-americana, embora muitos dos estudiosos brasileiros da religião reconheçam e valorizem a especificidade religiosa nacional e busquem chaves de intepretação que ajudem a entender esta especificidade, como a do sincretismo religioso. Poder contar com uma obra de tipo enciclopédico sobre a filosofia da religião, que também recolhe alguns autores de referência dos estudos da religião é de grande ajuda, pois torna possível uma visão geral do que já foi produzido e de quais as dificuldades e limites de cada perspectiva. Esse tipo de abordagem é uma provocação para o conjunto dos estudiosos brasileiros, pois os estimula a se perguntarem sobre os paradigmas que adotam e se não é o caso de se elaborar um paradigma próprio ao país.

O paradigma adotado por Greisch é o hermenêutico, entendendo hermenêutica como passagem. Esta posição pode parecer incômoda, pois fazer passar o outro significa dar-lhe a primazia, o que pode ser identificado como não ousar tomar a palavra. Trata-se, porém, de uma posição mais sutil e rica do que aparece à primeira vista. No fundo, ao fazer passar tantas perspectivas, o autor deixa-se ao mesmo tempo transformar por aquilo que faz passar, mas essa passagem não é passiva, pois ela leva à tomada de posição, mostra os limites, abre novas possibilidades. Alguns dos autores que ele faz passar são antagônicos, sob todos os pontos de vista. Ao deixar-se fecundar por eles, Greisch busca não a síntese entre posturas conceituais irreconciliáveis, mas elementos que possam tornar o estudo da religião mais rico e complexo.

No Brasil, os estudos de religião são, por um lado, realizados em várias faculdades de história, sociologia, psicologia, filosofia e etnologia/antropologia, além de ocuparem instituições que estudam geografia e estatística. Por outro lado, as faculdades de teologia, ligadas a várias denominações religiosas, estudam o específico de sua própria tradição espiritual, muitas vezes em perspectiva ecumênica e inter-religiosa. Surgiram também nas últimas décadas, sobretudo no 
âmbito da pós-graduação, as ciências da religião. $O$ interesse por uma hermenêutica da passagem, no caso dos estudos de religião no Brasil, é justamente abrir a possibilidade de mais passagens entre esses diferentes lugares e perspectivas do estudo do campo religioso nacional. Não para promover uma síntese, mas para possibilitar uma interfecundação mútua, como a que tem se realizado no âmbito da Associação Nacional de Pós-Graduação e Pesquisa em Teologia e Ciências da Religião (ANPTECRE), que busca fazer dialogar ciências da religião e teologia, mas que não conseguiu ainda fazer entrar nesse diálogo os saberes elaborados pela historiografia, sociologia, psicologia, etnologia, estatística, geografia.

\section{REFERÊNCIAS}

BLOCH, E. Le principe espérance. Paris: Gallimard, 1976-1988. 3 v.

BRETON, S. Passage, mon beau souci. In: CAPELLE, P.; HÉBERT, G.; POPELARD, M.-D. Le souci du passage: mélanges offerts à Jean Greisch. Paris: Cerf, 2004. p. 11-19.

CAPELLE, P.; HÉBERT, G.; POPELARD, M.-D. Le souci du passage. Mélanges offerts à Jean Greisch. Paris: Cerf, 2004.

CHRÉTIEN, J.-L. La voix nue. Une phénoménologie de la promesse. Paris: Minuit, 1990.

COHEN, H. La religion dans les limites de la philosophie. Paris: Cerf, 1990.

COHEN, H. La religion de la raison tirée des sources du judaïsme. Paris: PUF, 1994.

DITHEY, W. L'édification du monde historique dans les sciences de l'esprit. Paris: Cerf, 1988.

DITHEY, W. Le monde de l'esprit. Paris: Aubier, 1947. 2 v.

DUMÉRY, H. Philosophie de la religion: essai sur la signification du christianisme. Paris: PUF, 1957. v. 1: Catégorie de sujet, catégorie de grâce.

DUMÉRY, H. Philosophie de la religion: essai sur la signification du christianisme. Paris: PUF, 1957. v. 2: Catégorie de foi.

ELIADE, M. Le sacré et le profane. Paris: Gallimard, 1965. 
FARIA, P. A. C. Teologia e ciências da religião no panorama acadêmico brasileiro em diálogo com Paul Ricoeur. Belo Horizonte: FAJE, 2016.

FEUERBACH, L. L'essence du christianisme. Paris: Maspero, 1968.

GADAMER. H.-G. Vérité et méthode. Paris: Seuil, 1996.

GREISCH, J. Entendre d'une autre oreille: les enjeux philosophiques de l'herméneutique biblique. Paris: Bayard, 2006.

GREISCH, J. Hermeneutik und Metaphysik. München: Fink, 1993.

GREISCH, J. Herméneutique et grammatologie. Paris: CNRS, 1977.

GREISCH, J. L’âge herméneutique de la raison. Paris: Cerf, 1985.

GREISCH, J. L'arbre de vie et l'arbre du savoir. Les racines phénoménologiques de l’herméneutique heideggérienne. Paris: Cerf, 2000.

GREISCH, J. L'Herméneutique comme sagesse de l'incertitude. Paris: Vrin, 2015.

GREISCH, J. La parole heureuse. Martin Heidegger entre les choses et les mots. Paris: Beauchesne, 1987.

GREISCH, J. Le buisson ardent et les lumières de la raison: l'invention de la philosophie de la religion. Tome 2. Les approches phénoménologiques et analityques. Paris: Cerf, 2002b.

GREISCH, J. Le buisson ardent et les lumières de la raison: l'invention de la philosophie de la religion. Tome 3. Vers um paradigme herméneutique. Paris: Cerf, 2004.

GREISCH, J. Le buisson ardent et les lumières de la raison: l'invention de la philosophie de la religion. Paris: Cerf, 2002. Tome 1. Héritages et héritiers du XIXe siècle.

GREISCH, J. Ontologie et temporalité. Esquisse d'une interprétation intégrale de Sein und Zeit. Paris: Presses Universitaires de Frances, 1994.

GREISCH, J. Paul Ricœur: l'itinérance du sens. Grenoble : Jerôme Millon, 2001.

HEGEL, G. W. F. Leçons sur la philosophie de la religion. Paris: Vrin, 1954-1959. 3 v.

HEIDEGGER, M. Phénoménologie de la vie religieuse. Paris: Gallimard, 2005.

HEILER, F. La prière. Paris: Payot, 1931.

HENRY, M. C'est moi la vérité. Pour une philosophie du christianisme. Paris: Seuil, 1996. 
HENRY, M. Incarnation. Une phénnoménologie de la chair. Paris: Seuil, 2000.

HENRY, M. L'essence de la manifestation. Paris: PUF, 1990.

HUSSERL, E. Idées directrices pour une phénoménologie. Paris: 1985.

JAMES, W. L'expérience religieuse. Essai de psychologie descriptive. Paris:

Bibliothèque de l'homme, 1999.

JAMES, W. La volonté de croire. Paris: Flammarion, 1916.

KANT, I. La religion dans les limites de la simple raison (1793). In: KANT, I. Oeuvres complètes. Paris: Gallimard, 1986. v. 3. p. 9-242.

LACOSTE, J.-Y. Expérience et absolu. Questions disputées de l'humanité de l'homme. Paris: PUF, 1994.

MARION, J.-L. Dieu sans l'être. Paris: PUF, 1991.

MARION, J.-L. Étant donné. Essai d’une phénoménologie de la donation. Paris: PUF, 1997.

MARION, J.-L. L’idole et la distance. Paris: Le livre de poche, 1991.

MARZAL, M. Tierra encantada: tratado de antropologia religiosa de América Latina. Madrid: Trotta, 2002.

NIETZSCHE, F. Oeuvres complètes. Paris: Gallimard, 1977. 14 v.

OTTO, R. Le sacré. L'élement non rationnel dans l’idée du divin et sa relation avec le rationnel. Paris: Payot, 1995.

RAHNER, K. L'homme à l'écoute du Verbe. Fondements d'une philosophie de la religion. Tours : Mame, 1968.

RICOEUR, P. L'herméneutique biblique. Paris: Cerf, 2001.

RICOEUR, P. Lectures 3: aux frontières de la philosophie. Paris: Seul, 1994.

RICOEUR, P. Philosophie de la volonté. Paris: Aubier, 1950. v. 1: Le volontaire et l’involontaire.

RICOEUR, P. Philosophie de la volonté. Paris: Aubier, 1960. v. 2: Finitude et culpabilité. 2 v. ( I. L'homme faillible; II. La symbolique du mal).

RICOEUR, P. Soi-même comme un autre. Paris: Seuil, 1990.

RICOEUR, P.; LACOQUE, A. Penser la Bible. Paris: Seuil, 1998. 
ROSENZWEIG, F. L' étoile de la rédemption. Paris: Seuil, 1983.

SCHELER, M. Six essais de philosophie et de religion. Introduits par un commentaire de Hans usn von Balthasar. Fribourg : Éditions Universitaires, 1996.

SCHELLING, F. W. E. Les âges du monde (versions de 1811 et 1813). Paris: PUF, 1992.

SCHELling, F. W. E. Philosophie de la mythologie. Grenoble: Jérôme Millon, 1994.

SCHELling, F. W. E. Philosophie de la révélation. Paris: PUF, 1991-1998. 3 v.

SCHELLING, F. W. E. Philosophie et religion. La liberté humaine et controverses avec Eschenmayer. Paris: Vrin, 1988.

SCHLEIERMACHER, F. F. E. Discours sur la religion à ceux de ses contempteurs qui sont des esprits cultivés. Paris: Aubier-Montainge, 1944.

TILLICH, P. Philosophie de la religion. Genève: Labor et Fides, 1971.

TILLICH, P. Systematic Theology. Chicago: University of Chicago Press, 1951-1963. 3 v.

TROELTSCH, E. Histoire des religions et destin de la théologie: Oeuvres III. Genève: Labor et Fides; Paris: Cerf, 1996. v. 3.

VAN DER LEEUW, G. La religion dans son essence et ses manifestations. Phénoménologie de la religion. Paris: Payot, 1970.

WACH, J. Sociologie de la religion. Paris: Payot, 1955.

WITTGENSTEIN, L. Tractatus logico-philosophicus suivi de Investigations philosophiques. Paris Gallimard, 1961. 